\title{
Farnesylthiosalicylic acid induces caspase activation and apoptosis in glioblastoma cells
}

\author{
S Amos ${ }^{1}$, GT Redpath ${ }^{1}$, G Polar ${ }^{1}$, R McPheson ${ }^{2}$, D Schiff ${ }^{3}$ and \\ IM Hussaini ${ }^{*, 1}$ \\ 1 Department of Pathology, University of Virginia, Charlottesville, VA 22908, \\ USA \\ 2 Department of Endocrinology, University of Virginia, Charlottesville, VA 22908 , \\ USA \\ ${ }^{3}$ Department of Neurology, University of Virginia, Charlottesville, VA 22908, \\ USA \\ * Corresponding author: IM Hussaini, Department of Pathology, University of \\ Virginia, MR5 Room 3324, 415 Lane Road, Charlottesville, VA 22908, USA. \\ Tel: + 1434924 0110; Fax: + 1434924 9177; \\ E-mail: imh5c@virginia.edu
}

Received 14.1.05; revised 16.8.05; accepted 18.8.05; published online 21.10.05 Edited by CJ Thiele

\begin{abstract}
Primary glioblastomas (GBMs) commonly overexpress the oncogene epidermal growth factor receptor (EGFR), which leads to increased Ras activity. FTA, a novel Ras inhibitor, produced both time- and dose-dependent caspase-mediated apoptosis in GBM cell lines. EGFR-mediated increase in ${ }^{3} \mathrm{H}$ thymidine uptake was inhibited by FTA. FACS analysis was performed to determine the percent of apoptotic cells. The sub-Go population of GBM cells was increased from 4.5 to $13.8 \%$ (control) to over $45-53.6 \%$ in FTA-treated cells within $24 \mathrm{~h}$. Furthermore, FTA also increased the activities of both caspase-3 and -9, and PARP cleavage. Treatment of GBMs with FTA before or after EGF addition to the cultures blocked phosphorylation of Akt and mitogen-activated protein kinases (MAPK). FTA also significantly reduced the amount of EGFinduced Ras-GTP as reflected by a decrease in the level of Ras bound to Raf-RBD-GST. This study demonstrates that inhibition of Ras methylation may provide a therapeutic target for the treatment of GBMs overexpressing EGFR.

Cell Death and Differentiation (2006) 13, 642-651.

doi:10.1038/sj.cdd.4401783; published online 21 October 2005
\end{abstract}

Keywords: glioblastoma; farnesylthiosalicylic acid; apoptosis; epidermal growth factor receptor; Ras; caspase

Abbreviations: GBM, Glioblastoma; FTA, Farnesylthiosalicylic acid; EGFR, Epidermal Growth Factor Receptor; MAPK, Mitogenactivated protein kinase

\section{Introduction}

Glioblastoma multiforme (GBM) is the most malignant diffusetype astrocytic neoplasm, representing over half of all astrocytic tumors. ${ }^{1}$ Diffusely infiltrative astrocytomas exhibit micro-infiltrative growth into surrounding brain tissue, a capacity for distal spread throughout the neuraxis, and a significant potential for progressive increases in malignancy over time. Such aggressive and invasive growth is the hallmark feature that gives rise to high morbidity and mortality associated with GBM. Resistance to conventional adjuvant, for example, chemotherapy and radiation, has posed major challenges in the treatment of patients with GBMs. ${ }^{2-5}$ The molecular basis of GBM resistance has not been fully elucidated. However, overexpression or amplification of epidermal growth factor receptor (EGFR), ${ }^{6}$ PTEN and p53 mutations $\mathrm{s}^{7,8}$ and expression of PKC- $\eta^{9}$ have been postulated to contribute to the lack of efficacy of chemotherapy and radiation in the treatment of GBMs and other cancers. Activation of EGFR stimulates a number of signal transduction pathways, including the Ras/Raf/mitogen-activated protein kinase (MAPK), Ras/PI3K/Akt/mTOR and PKC signaling pathways. ${ }^{10,11}$

The three mammalian ras genes yield four Ras proteins: $\mathrm{H}$-Ras, N-Ras, K-Ras4A, and K-Ras4B. ${ }^{12}$ The two K-Ras proteins result from alternative splicing of the fourth exon of a single gene. ${ }^{13}$ Ras proteins are membrane-anchored guanine-nucleotide binding proteins that function as biological switches that signal through tyrosine kinase and G-protein coupled receptors to cytoplasmic MAPK and Akt signaling cascades. ${ }^{14,15}$ Activation of growth factor receptor pathways increases the level of active Ras after formation of a multiprotein complex in the cell membrane which includes SHC, SOS, and Grb-2. Ras is synthesized and modified in the cytosol before it is anchored at the membrane. Before Ras is anchored to the membrane, it is first posttranslationally modified at the carboxyl terminal region with the C-15 prenyl group, farnesyl. ${ }^{16-18}$ After synthesis, each form of Ras is prenylated in the cytoplasm via one of three different enzymes: farnesyl transferase (FTase) and geranylgeranyl transferases I and II (GGTase). ${ }^{19-21}$ The prenylated Ras proteins are further methylated by prenylated protein methyltransferase (PPMT) before being anchored to a specific membrane 'acceptor site'. ${ }^{22}$ The inhibitors (FTIs) of FTase and GGTase are in various stages of clinical trials and the results obtained with FTls alone were disappointing. ${ }^{23}$ Since Ras could be modified by FTase or GGTase I and II, inhibiting one of these enzymes alone would not completely block the processing of Ras in the cytoplasm and anchoring of Ras at the membrane. Thus, the inhibition of PPMT, which methylates both FTase and GGtase-processed Ras, is potentially a more attractive therapeutic intervention than blocking either FTase or GGTase alone.

Inhibition of PPMT by either FTA or farneylthiosalicylate (FTS) has been shown to prevent the attachment of Ras to the cell membrane, leading to an increase in degradation of the guanine nucleotide. FTA inhibits the growth of $\mathrm{H}$-Ras transformed EJ cells and K-Ras transformed fibroblasts. ${ }^{24}$ In the present study, we report that FTA-induced apoptosis, increased caspase-3/9 activity and inhibited EGF-induced increase in ${ }^{3} \mathrm{H}$-thymidine incorporation in GBM cells. The 
PPMT inhibitor also blocked EGF-induced Ras activation, MAPK and Akt phosphorylation.

\section{Results}

\section{Effect of FTA on GBM survival and cell proliferation}

Four GBM cell lines (U-1242 MG, U-251 MG, U-87 MG, and $\mathrm{U}-373 \mathrm{MG}$ ) with different genetic alterations in p53 and PTEN were treated with different concentrations $(0.1-10 \mu \mathrm{M})$ of FTA for 24 or $48 \mathrm{~h}$. We found that FTA was more effective after $48 \mathrm{~h}$. At a concentration of $10 \mu \mathrm{M}$; the FTA killed all the four cell lines within $48 \mathrm{~h}$ (Figure 1). The PPMT inhibitor was less effective in U-251 MG cells at lower concentrations but effective at 5 and $10 \mu \mathrm{M}$. We repeated this study three times and consistently obtained similar results. The concentration of FTA that killed $50 \%$ of the cells is $2.5+0.2 \mu \mathrm{M}(n=3)$ in $\mathrm{U}-1242 \mathrm{MG}$ cells, $6.5 \pm 0.4 \mu \mathrm{M}(n=3)$ in U-251 MG cells, $2.0 \pm 0.3 \mu \mathrm{M}(n=3)$ in U87 MG cells, and $3.0 \pm 0.4 \mu \mathrm{M}(n=3)$ in U-373 MG cells.

In a separate experiment, we compared the relative potencies of FTA and other pharmacological inhibitors that have been shown to regulate the growth of GBM cells and other tumors. Even though we have previously demonstrated that bisindolylmaleimide (BIM) and the MEK inhibitor (U-0126) inhibited thymidine uptake in GBMs as cytostatic agents, both kinase inhibitors at concentration range of $1-10 \mu \mathrm{M}$ failed to significantly reduce the number of GBM cells $48 \mathrm{~h}$ posttreatment (data not shown). The classical PKC inhibitor (Gö 6976) slightly inhibited (18\%) GBM cells viability at $10 \mu \mathrm{M}$. In Figure 2, etoposide (topoisomerase 2 inhibitor) and anisomycin (c-Jun $\mathrm{N}$-terminal kinase activator) significantly reduced

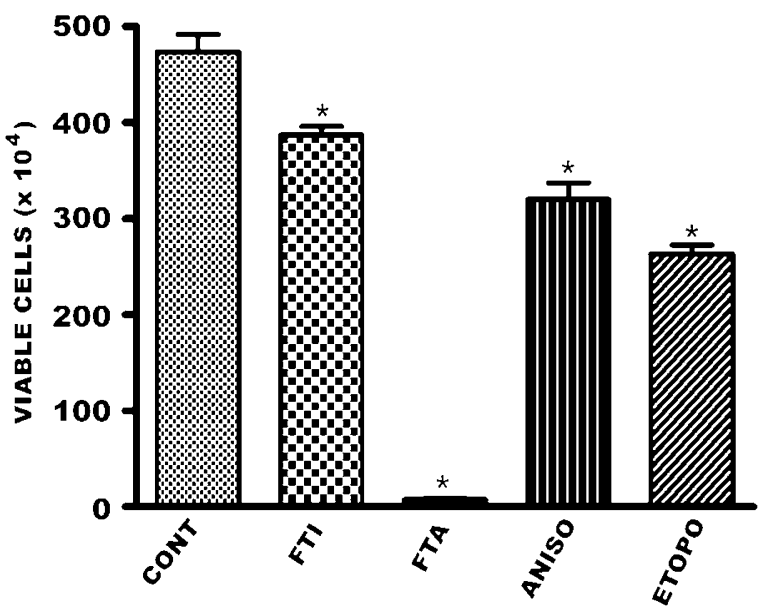

Figure 2 Effect of different pharmacological agents on GBM cell survival. U$251 \mathrm{MG}$ cells were treated with $0.05 \% \mathrm{v} / \mathrm{v}$ DMSO (CONT), $10 \mu \mathrm{M}$ of FTase inhibitor II (FTI), FTA, anisomycin (ANISO; JNK activator) and etoposide (ETOPO; topoisomerase II inhibitor) for $48 \mathrm{~h}$. The cells were washed three times with serum-free $\alpha$-MEM, photographed (original magnification was $\times 100$ ) and counted for viable cells $\left(n=3,{ }^{\star} P<0.05\right)$
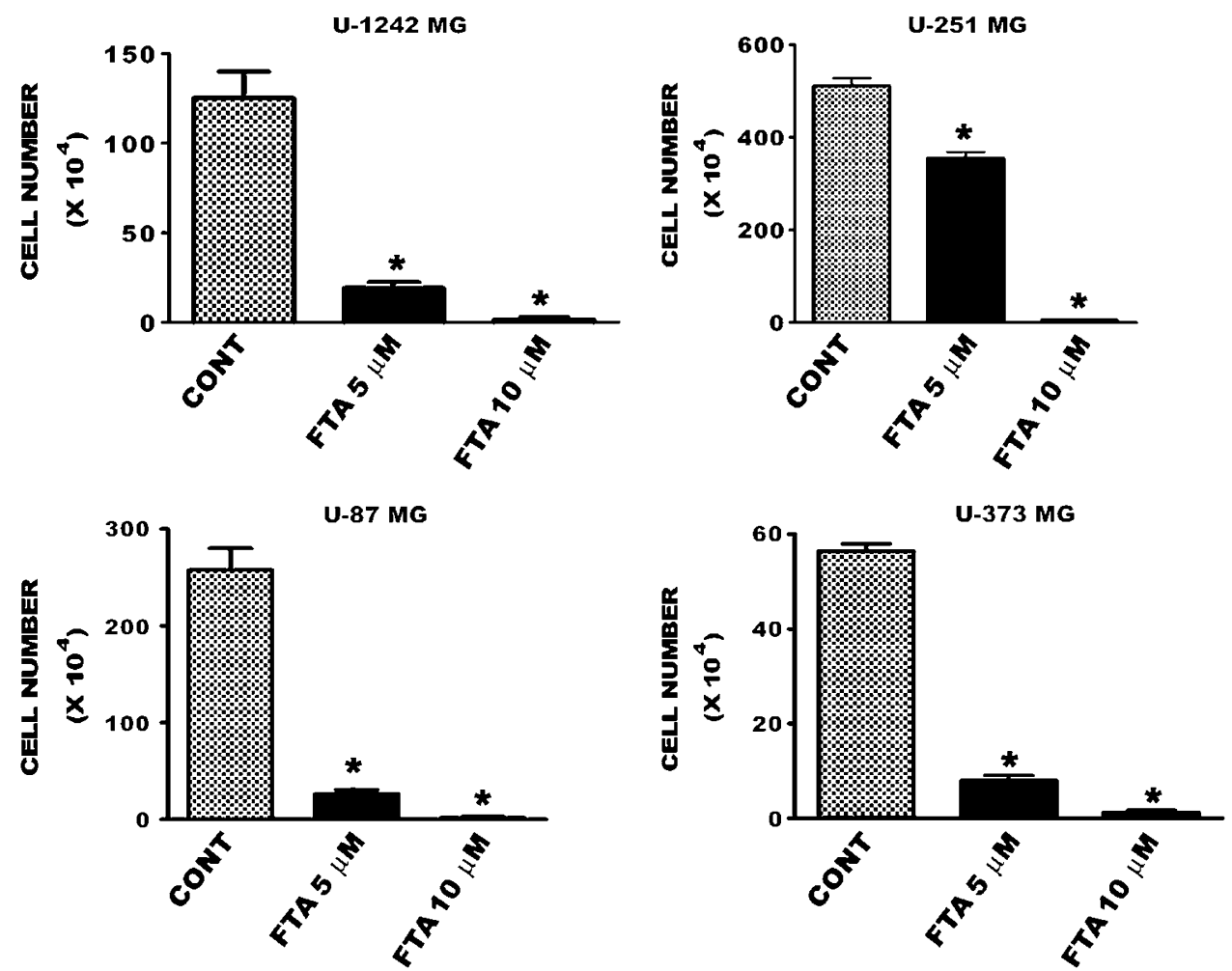

Figure 1 FTA induces concentration-dependent cell death in GBM cells - cells were treated with different concentrations of FTA for $48 \mathrm{~h}$, cells were washed three times and then photographed. Viable cells were determined by Trypan blue exclusion. Adherent cells were released from the plate with $0.05 \%$ w/v trypsin-EDTA $(0.53 \mathrm{mM})$ for $2 \mathrm{~min}$, centrifuged, and resuspended in serum-free $\alpha$-MEM. Trypan blue was added and cells counted under the microscope with a hemocytometer $(n=3$, $\left.{ }^{\star} P<0.05\right)$ 
the number of viable GBM cells by 40 and $20 \%$, respectively. The inhibition of Ras prenylation by FTase (FTase inhibitor II) or GGTase (GGTI-298) alone did not significantly reduce GBM viability. In contrast, the same concentration $(10 \mu \mathrm{M})$ of FTA completely killed the U-251 cells (Figure 2).

The EGFR is overexpressed and amplified in primary GBMs and the stimulation of this tyrosine kinase receptor activates a number of signaling pathways, including the Ras/ Raf/MEK/MAPK pathway as well as PI3K/Akt pathway. To determine whether FTA affects the functional activation of this receptor, we assessed the effect of the Ras inhibitor on EGFinduced thymidine uptake, as a measure of cell proliferation in GBM cells. The U-373 MG and U-251 MG cells have mutations in PTEN and $\mathrm{p} 53^{25}$ and both express PKC- $\eta,{ }^{9}$ and thus, we decided to concentrate on U-1242 MG, U-87 MG and U-251 MG that have distinct characteristics. EGF $(25 \mathrm{ng} / \mathrm{ml})$ evoked $68 \%$ increase in thymidine uptake in U-1242 MG cells, 131\% increase in U-251 MG cells and $40 \%$ increase in U-87 MG, which was completely blocked by FTA added 60 min before EGF (Figure 3a). Since in patients with GBM harboring receptor tyrosine kinase overexpression and/or amplification the Ras pathways are already activated, we determined the effect of FTA after the cells have been challenged with EGF. Addition of FTA $(10 \mu \mathrm{M})$ to the cultures $60 \mathrm{~min}$ post-EGF also inhibited thymidine uptake when assessed $24 \mathrm{~h}$ after mitogen incubation with the GBM cells (Figure 3b).

\section{FTA increases sub-G。 GBM population}

Cell death could be programmed cell death (apoptosis) or necrosis. To determine whether the FTA-induced cell death is indeed apoptosis, we treated the three GBM cells with FTA $(10 \mu \mathrm{M})$ for $24 \mathrm{~h}$ in serum-free $\alpha$-MEM and assessed for propidium iodide $(\mathrm{PI})$ stained DNA content using FACS analysis. Following FTA treatment, the sub- $\mathrm{G}_{0}$ apoptotic cells increased from 13.8 to $53.6 \%$ in U-1242 MG cells, from 4.25 to $47.5 \%$ in U-251 MG cells and from 6.53 to $45.4 \%$ in U-87 MG cells.

\section{FTA-induced apoptosis is associated with caspase activation and poly (ADP) ribose polymerase (PARP) cleavage}

Since caspase-3 activation is implicated in apoptosis in GBM cells, ${ }^{9}$ we investigated the activation of caspase-3, its upstream activator (caspase-9) and caspase-8 in response to FTA $(10 \mu \mathrm{M})$. We examined cleavage products and activities of these caspases by western blot analysis and colorimetric assay, respectively. FTA treatment of GBM cells increased caspase-3 activation (Figure 4) and -9 activation but not caspase-8 activation (data not shown). The FTAinduced increase in caspase- 3 activation was blocked by the specific inhibitor (Ac-DEVD-CHO) of caspase 3. In another set of experiments, we determined the cleavage of caspase 3 , as a measure of its activation. Caspase- 3 ( $32 \mathrm{kDa})$ was activated by FTA in all three GBM cell lines (data not shown), as determined by the generation of cleavage product of $17 \mathrm{kDa}$. The cleavage of caspase- 3 was detected both at 24 and $48 \mathrm{~h}$ post FTA treatment. PARP is one of the death substrates cleaved by caspase- 3 and we examined whether the activation of caspase- 3 was accompanied by the cleavage of PARP. Figure 5 shows the cleavage of pro-form PARP ( $115 \mathrm{kDA})$ to the active form ( $85 \mathrm{kDA})$ both at 24 and $48 \mathrm{~h}$ postFTA treatment of GBM cells.

\section{FTA blocks the activation Ras by EGF}

In view of the fact that activated Ras binds specifically to Rasbinding domain (RBD) of Raf effector protein, Raf-RBD can be used as a probe to isolate Ras-GTP. ${ }^{26}$ First, we established the basal levels of H-Ras, K-Ras, and N-Ras in the three GBM cell lines. The expression level of $\mathrm{N}$-Ras was lower than those of H-Ras or K-Ras in U-1242 MG and U-87 MG cells. However, the U-251 MG cells that are less sensitive to FTA than U-124 MG and U-87 MG cells have similar levels of Ras isoforms. We then stimulated the GBM cell lines with EGF $(25 \mathrm{ng} / \mathrm{ml})$ in the absence of FTA for $2,5,10$, or $30 \mathrm{~min}$, and assessed the levels of activated Ras using Raf-RBD-GST pulldown assay. Treatment of the GBM cells for 2 min induced the most robust expression of active Ras (Figure 6a). We used this treatment period with EGF to determine the effect of FTA on Ras activation. In the pulldown assay, FTA treatment for 60 min reduced EGF-induced Ras activation by over $80 \%$ (Figure 6b). Since the activation of Ras by EGF returned to basal level after $60 \mathrm{~min}$, we were unable to determine the effect of FTA after the addition of EGF. We also complemented the pulldown assay with an ELISA (Ras GTPase Chemi ELISA Kit) to determine the effect of FTA on EGF-induced Ras activation (Figure 6c). FTA pretreatment for $60 \mathrm{~min}$ blocked EGF-induced increase in Ras to control baseline levels in all the three cell lines.

\section{FTA blocks EGF-induced phosphorylation of MAPK and Akt}

Ras stimulation has been shown to activate both Raf/MEK/ MAPK and PI3K/Akt pathways. ${ }^{10,11}$ To examine whether the inhibition of methylation of prenylated Ras by FTA blocks the Raf/MEK/MAPK and PI3K/Akt pathways, we serum-starved cells for $24 \mathrm{~h}$ and pretreated GBM cells with FTA $(10 \mu \mathrm{M})$ for $60 \mathrm{~min}$ before challenging them with EGF $(25 \mathrm{ng} / \mathrm{ml})$ for $15 \mathrm{~min}$. As expected, EGF evoked a robust phosphorylation of both ERK1 (44-kDa) and $2(42-\mathrm{kDa})$ and induced a significant phosphorylation of Akt at serine 473 (Figure 7a). Pretreatment with FTA completely abrogated the effect of EGF on both ERK $1 / 2$ as well as Akt phosphorylation. There was no significant change in the levels of total ERK and Akt in either EGF or FTA-treated cells (Figure 7a). EGF induced a robust and sustained MAPK phosphorylation for at least $60 \mathrm{~min}$ and then the phosphorylation declined thereafter. We used the 60 min MAPK phosphorylation window to test whether treatment with FTA after the cells have been incubated with EGF would block MAPK phosphorylation. Addition of FTA $(10 \mu \mathrm{M})$ for 45 min after 15-min treatment of cells with EGF $(25 \mathrm{ng} / \mathrm{ml})$ inhibited the phosphorylation of both ERK1 and two by approximately $65 \%$ (Figure $7 \mathrm{~b}$ ). 
a
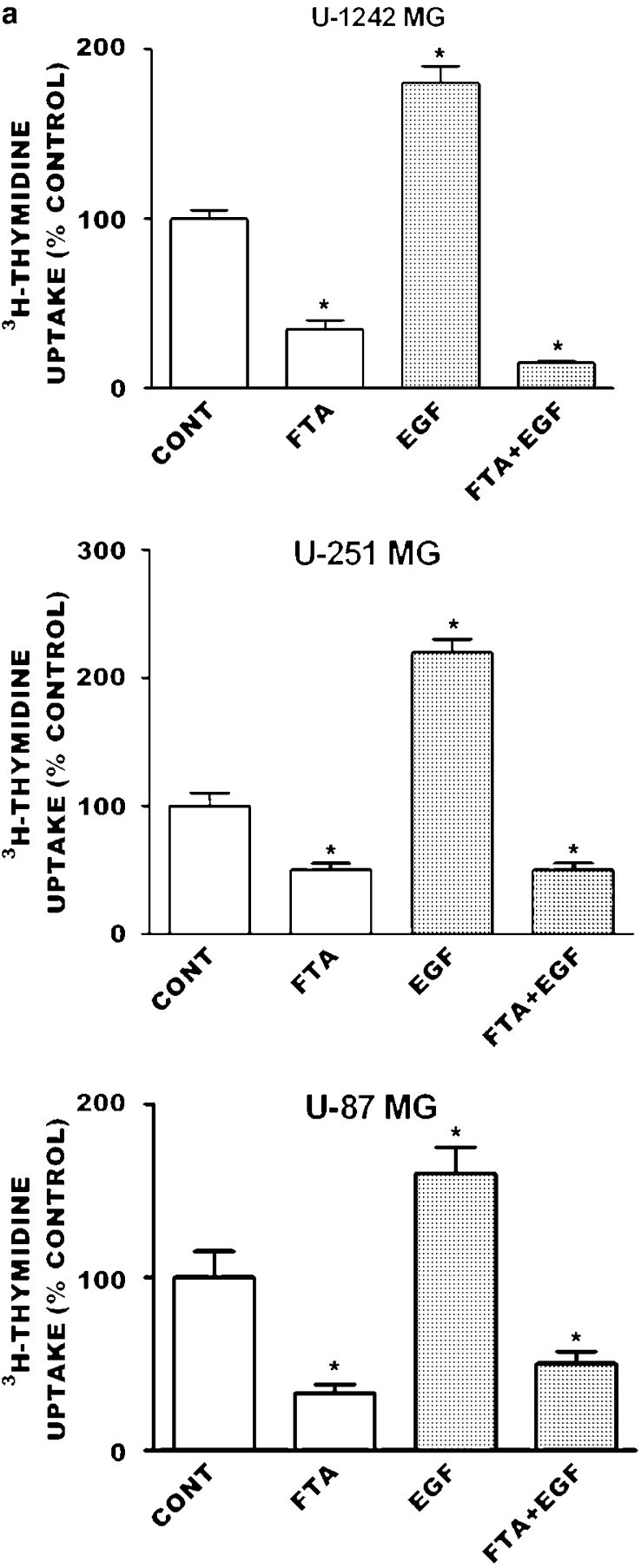
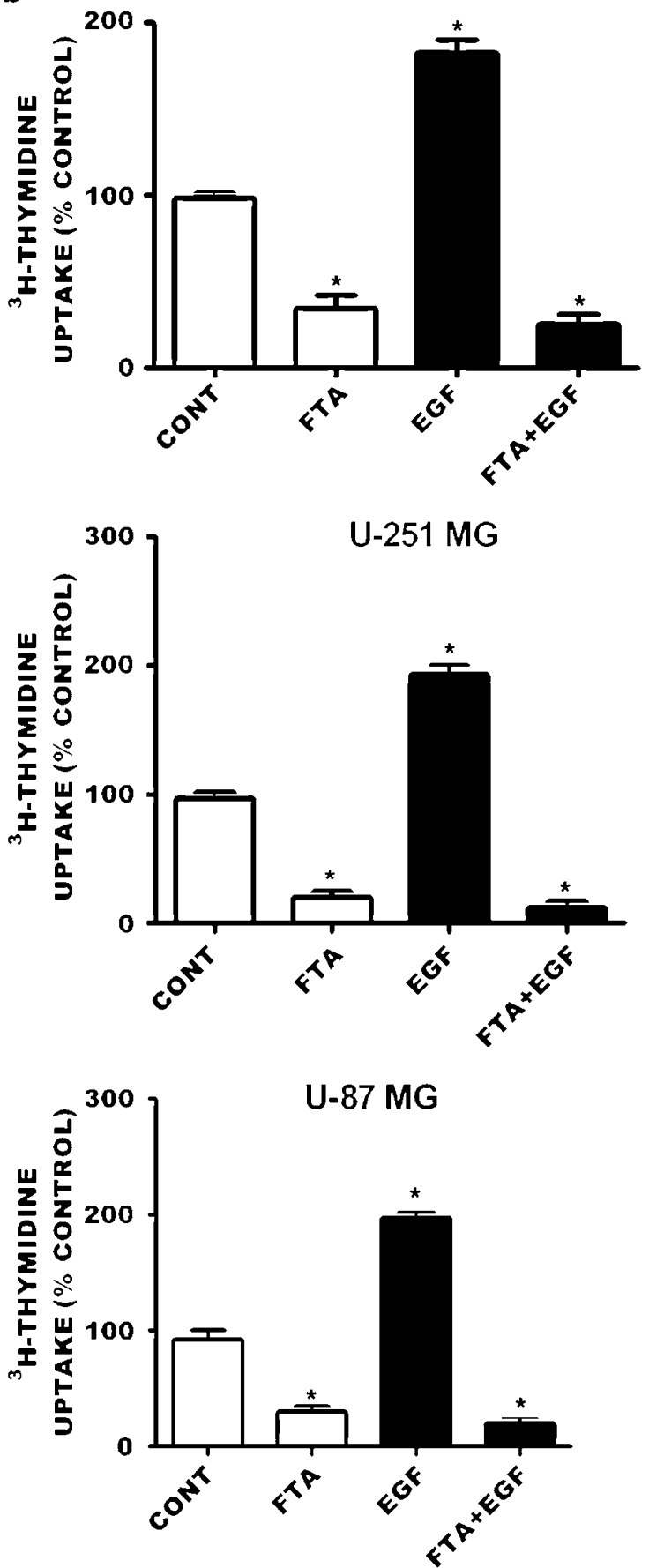

Figure 3 Effect of FTA on EGF-induced increase in ${ }^{3} \mathrm{H}$-thymidine incorporation in GBM cells. Cultures of U-1242 MG, U-251 MG and U-87 MG cells treated with either FTA $(10 \mu \mathrm{M})$, EGF $(25 \mathrm{ng} / \mathrm{ml})$ or a combination of FTA and EGF in serum-free $\alpha$-MEM for $20 \mathrm{~h}$. Panel (a) FTA was added to the culture $30 \mathrm{~min}$ before EGF. Panel (b) FTA was added to the cells $30 \mathrm{~min}$ after EGF. The cells were then pulsed with ${ }^{3} \mathrm{H}$-thymidine $(2 \mu \mathrm{Ci} / \mathrm{ml})$ for $4 \mathrm{~h}$ and harvested for radioactivity determination $\left(\mathrm{CONT}=\right.$ control; $\left.n=3,{ }^{*} P<0.05\right)$

\section{Discussion}

Receptor-mediated Ras hyperactivity observed in malignant gliomas has been attributed to the aberrant expression and overactivity of membrane tyrosine kinase receptors, including EGFR and platelet-derived growth factor receptor (PDGFR).
Ras is a key intermediate in signal transduction pathways, linking membrane-bound receptor tyrosine kinases to a downstream cascade of protein kinase effector molecules.

Following prenylation, Ras is methylated by prenylated protein methyl transferase (PPMT) and regardless of whether Ras is prenylated by FTase or GGTases I and II, PPMT 

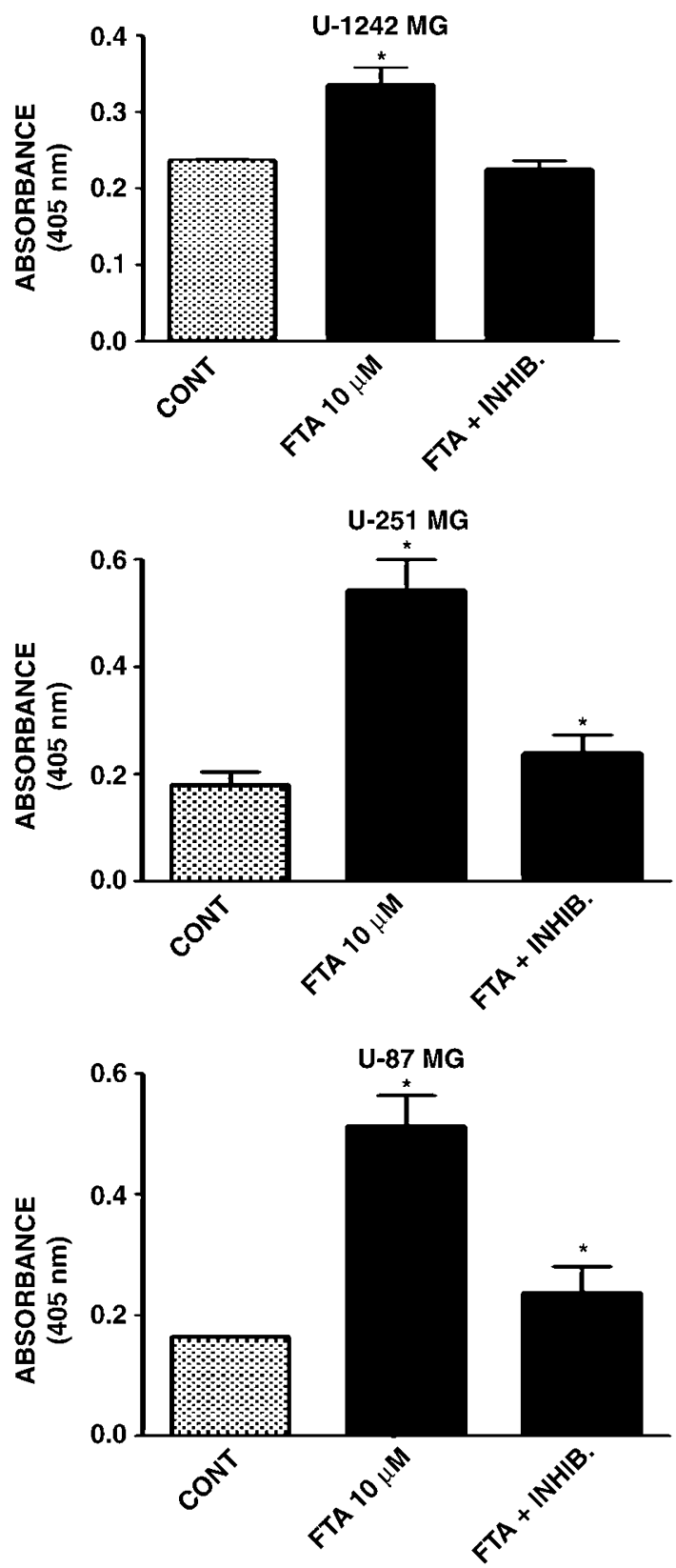

Figure 4 FTA-induced cleavage of caspase- 3 and increased caspase- 3 activity. Caspase- 3 activity was assayed with lysate from control cells and cells treated with FTA $(10 \mu \mathrm{M})$ for $24 \mathrm{~h}$ in the absence and presence of a specific caspase-3 inhibitor (Ac-DEVD-CHO; $25 \mu \mathrm{M})\left(n=3,{ }^{\star} P<0.05\right)$

methylates the prenylated Ras. Therefore, inhibitors of PPMT should be better therapeutic agents than those of FTase or GGTase alone. A number of FTase and GGTase inhibitors have been evaluated preclinically as single agents, but most have not progressed into clinical development. The potential for cross-prenylation of K-Ras by FTase and GGTase implies that GGTase may be able to restore the function of Ras and other proteins. If so, this would have implications with regard to intrinsic sensitivity of tumors to therapeutic agents targeting FTase and the development of resistance. In the present study, we demonstrated that FTA induced apoptosis in GBM
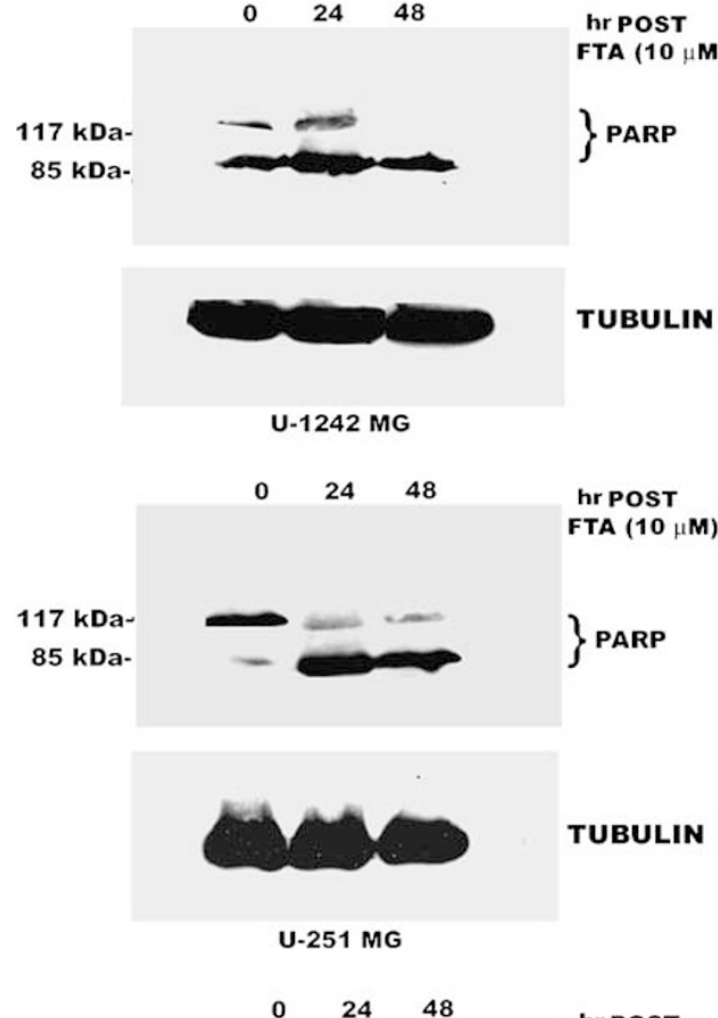

hr POST

FTA $(10 \mu M)$

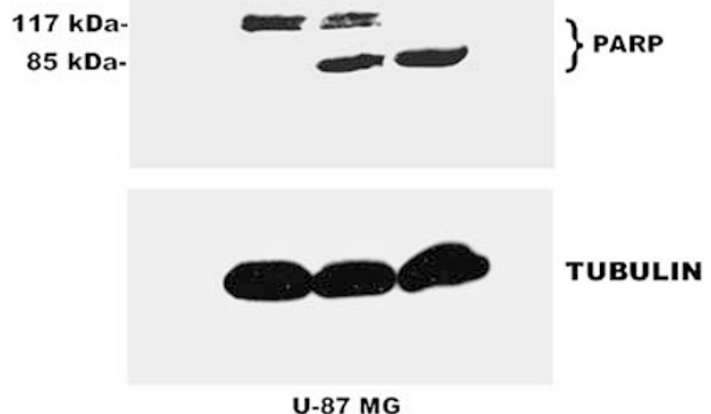

Figure 5 FTA induced the cleavage of PARP - GBM cells (U-1242 MG, U-25 $\mathrm{MG}$ and U-87 MG) were treated with $10 \mu \mathrm{M}$ of FTA for $24 \mathrm{~h}$ and $48 \mathrm{~h}$ in serumfree $\alpha$-MEM and Western blotting was performed with antibody against both uncleaved and cleaved PARP

cells by inhibiting Ras-mediated phosphorylation of MAPK and Akt and thereby sensitizing caspase-9 and -3 to endogenous proapoptotic stimuli.

Several experiments presented in this study suggest that FTA induced cell death in GBM cell culture by caspasedependent apoptosis. First, FTA treatment of GBMs resulted in dose- and time-dependent cell death (Figure 1) that was accompanied by an increase in sub-Go cell population. Secondly, the apoptotic signaling pathway involving caspase -9 and -3 and proteolysis of PARP was activated by FTA in all the GBM cell lines tested. The FTA-induced increase in caspase-3 activity was blocked by a specific inhibitor of caspase-3 (Figure 4). Thirdly, FTA blocked EGF-induced Ras activation (Figure $6 \mathrm{~b}$ and $\mathrm{c}$ ) and phosphorylation of MAPK and 
a

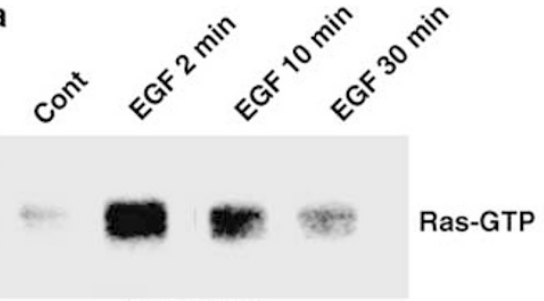

U-1242 MG

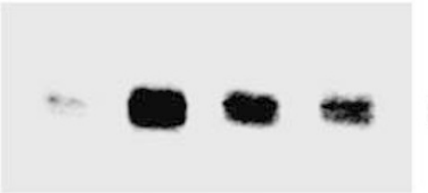

U-251 MG

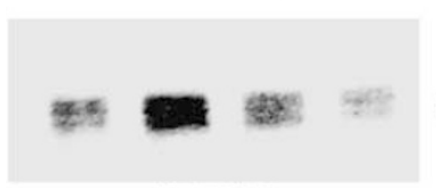

U-87 MG

b

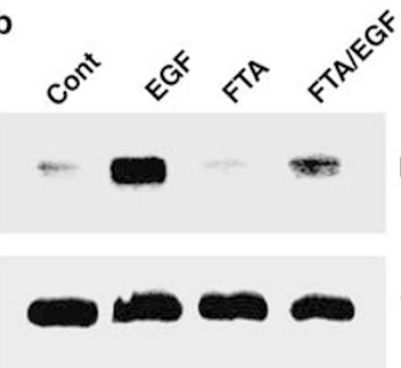

U-1242 MG

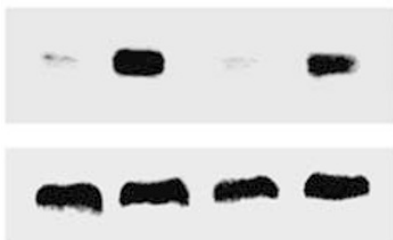

U-251 MG

Ras-GTP

Ras-GTP

Ras-GTP c
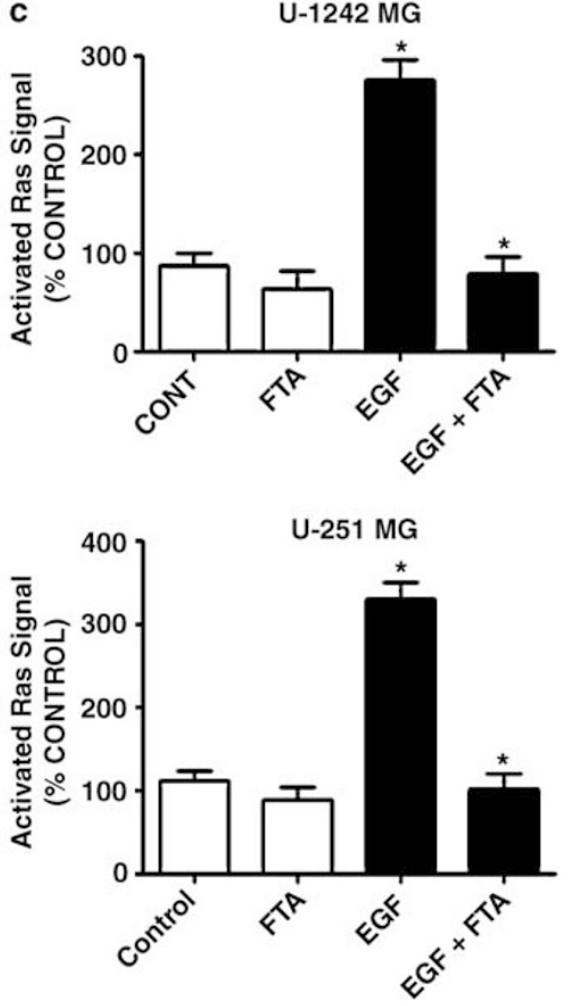

TOTAL K-Ras

TOTAL K-Ras

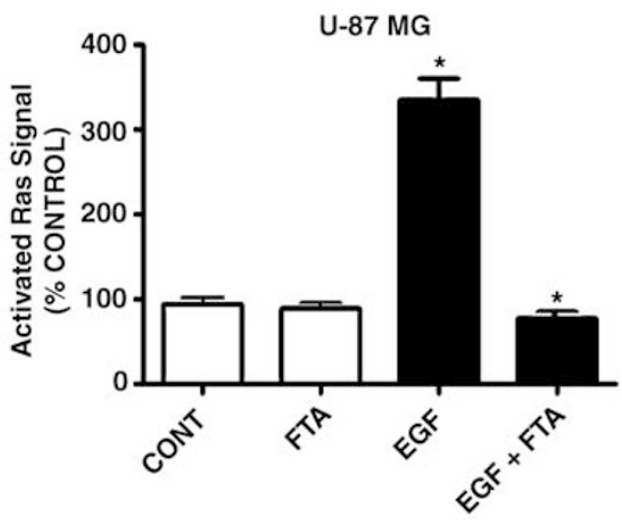

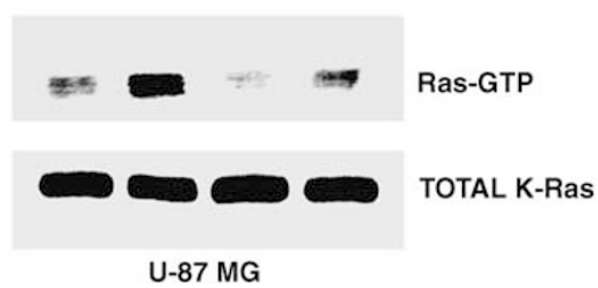

Figure 6 FTA blocked EGF-induced Ras activation. Panel (a) confluent cells were serum-starved overnight and treated with EGF $(25 \mathrm{ng} / \mathrm{ml})$ for 2,10 , or $30 \mathrm{~min}$. Cells were lyzed and subjected to pulldown assay with Raf-RBD-GST. The amount of Ras-GTP was determined by immunoblotting using pan-Ras antibody. Panel (b) Cells were incubated in serum-free media overnight and treated with FTA $(10 \mu \mathrm{M})$ for $60 \mathrm{~min}$ before the addition of EGF ( $25 \mathrm{ng} / \mathrm{ml})$ for 2 min. Control and EGF lanes have DMSO $(0.1 \% \mathrm{v} / \mathrm{v})$ at the time FTA was added to the cells. Cells were lyzed and subjected to pulldown assay with Raf-RBD-GST. The amount of Ras-GTP was determined by immunoblotting using pan-Ras antibody. K-Ras was used as a loading control in a regular western blot analysis. Panel (c) Cells were treated as described in Panel (b) Cells were lyzed and subjected to ELISA assay with Raf-RBD-GST. The amount of Ras-GTP was determined by chemiluminescence

Akt (Figure 7). Both MAPK and Akt are known direct negative regulators of caspase- 9 activation. ${ }^{27}$ Many proapoptotic signals activate caspase- 9 , an initiator protease that activates caspase-3 and downstream caspases to initiate cellular destruction. However, survival signals can impinge on this pathway and suppress apoptosis.

Akt is known to phosphorylate caspase- 9 and thus prevents its activation by stimuli or factors that induce apoptosis. ${ }^{27}$ 

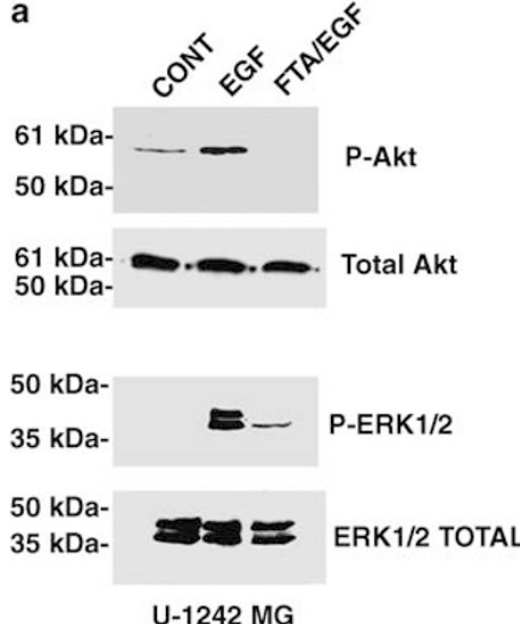

b

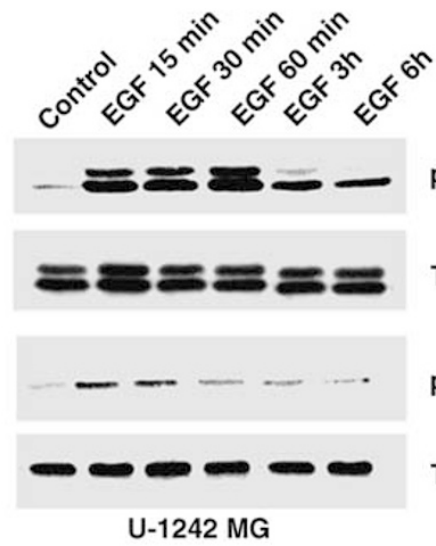

p-ERK1/

Total ERK

p-Akt (Ser 473)

Total Akt

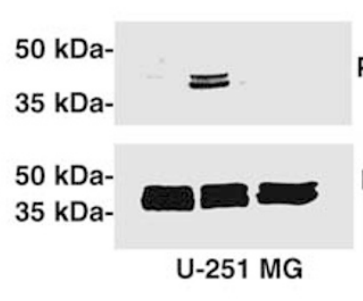

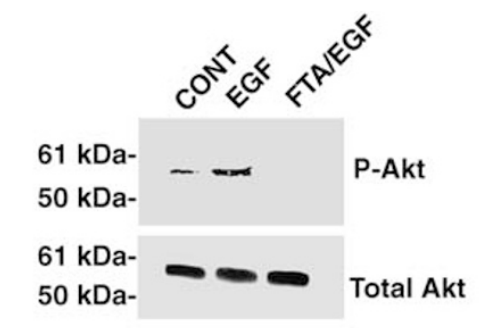

Total Akt
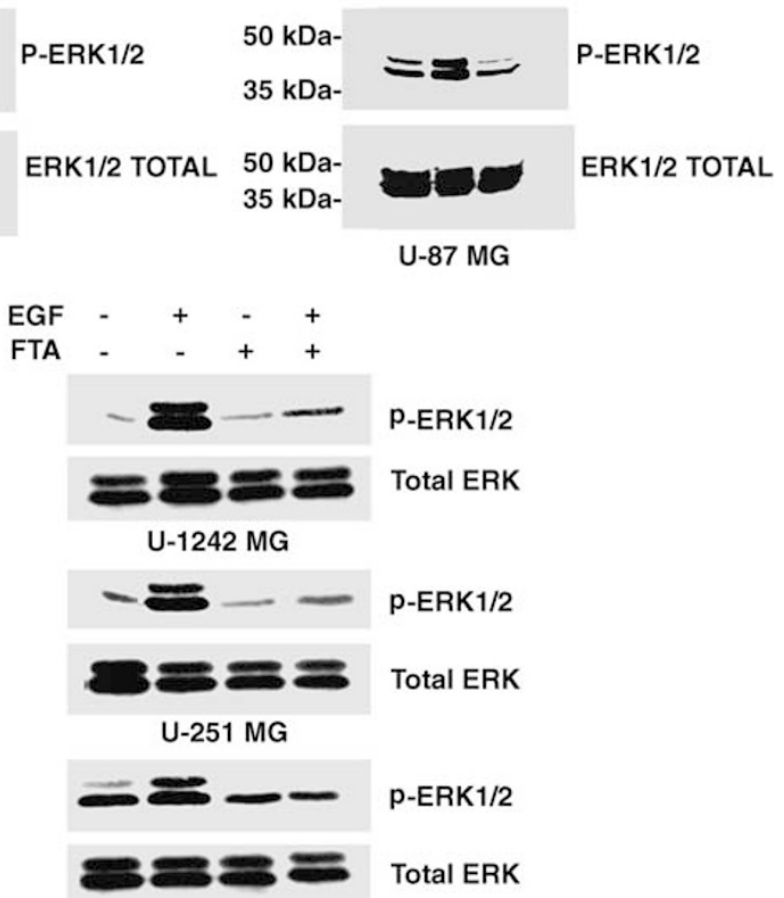

p-ERK1/2

Total ERK

U-87 MG

Figure 7 FTA Blocked EGF-induced Phosphorylation of ERK and Akt in GBM Cells. Panel (a) - Cells were pretreated with FTA for 30 min before the addition of EGF. ERK Phosphorylation Cells were incubated in serum-free media overnight and treated with FTA (10 $\mu \mathrm{M})$ for $60 \mathrm{~min}$ before the addition of EGF ( $25 \mathrm{ng} / \mathrm{ml}$ ) for $15 \mathrm{~min}$. Control and EGF lanes have DMSO $(0.1 \% \mathrm{v} / \mathrm{v})$ at the time FTA was added to the cells. Western blotting was performed with dual-phospho specific antibody against both ERK1/2. Akt Phosphorylation. Blot for ERK phosphorylation was stripped and reprobed with phospho-specific antibody against Akt Ser473 and an antibody against total Akt (Cell Signaling, Technology, Boston MA). Panel (b) - The time course (15, 30, 60 min, 3 and $6 \mathrm{~h}$ ) for the activation of MAPK and Akt were determined first. EGF was added to the cells for $15 \mathrm{~min}$, followed by FTA for $45 \mathrm{~min}$ and MAPK phosphorylation was determine by Western blotting

Since FTA blocked EGF-induced Akt phosphorylation, one may argue that the PPMT inhibitor would prevent the phosphorylation of caspase- 9 by Akt. This would then make caspase-9 more sensitive to inducers of apoptosis. Similarly, activation of the Ras/Raf/MEK/MAPK pathway is associated with protection of cells from apoptosis and inhibition of caspase-3 activation. ${ }^{28-31}$ The MAPK pathway inhibits caspase- 9 activity by direct phosphorylation. ${ }^{32}$ Allan et al. ${ }^{32}$ showed that caspase- 9 was phosphorylated at Thr 125, a conserved MAPK consensus site targeted by ERK2 in vitro, in a MEK-dependent manner in cells stimulated with epidermal growth factor (EGF) or 12-O-tetradecanoylphorbol-13acetate. ${ }^{32}$ Phosphorylation at Thr 125 was sufficient to block caspase- 9 processing and subsequent caspase- 3 activation. Thus, blocking Ras activation and ERK2 phosphorylation by FTA may also sensitize caspase- 9 and -3 to proapoptotic stimuli.
The mechanism of action of FTA is associated primarily with the inhibition of PPMT and dislodgment of Ras from the plasma membrane, thereby accelerating Ras degradation. ${ }^{33}$ In addition, FTA seems to affect mainly Ras proteins in their activated state. ${ }^{24}$ This specific action of FTA is claimed to be responsible for the lack of cytotoxicity in vivo. ${ }^{34}$ In animal studies, FTA has been demonstrated to be relatively safe. ${ }^{34,35}$ The lack of overt toxic effects in these animals indicates that FTA has a reasonable large margin of safety. These studies showed that the $\mathrm{LD}_{50}$ of FTA was between 75 and $100 \mathrm{mg} /$ kg. ${ }^{34}$ Intraperitoneal administration of FTA (5 mg per $\mathrm{kg}$ ) in mice did not significantly affect body weight or weights of the adrenal gland, spleen, heart, kidney, liver, and pancreas. ${ }^{34}$ Similarly, FTA did not affect blood counts (erythrocytes, leukocytes, or platelets), creatine, liver enzymes, or creatine kinase (all isoforms). ${ }^{33}$ In another study, FTA inhibited melanoma tumor growth by $90 \%$ with no observable 
histopathologic toxic effect in lung, liver, brain, kidney, or small intestine. ${ }^{35}$ Even though these studies suggested lack of cytotoxicity of FTA in vivo, we cannot exclude the possibility that FTA may also interfere with the action of other prenylated proteins that are modified by $\alpha$-carboxyl methylation, such as Rac/Rho family of GTPases, the $\gamma$-subunits of the large Gproteins, some of the nuclear lamins and the retinal cGMP phosphodiesterase (Reviewed in Clarke ${ }^{36}$ ).

Recently, FTA has been reported to be effective in suppressing growth of a number of cancers in vitro, including prostate cancer and melanoma. ${ }^{37,38}$ In both studies higher concentrations $(50-100 \mu \mathrm{M})$ were used compared with $1-10 \mu \mathrm{M}$ in our studies. Unlike gliomas that rarely have Ras mutations, prostate cancers and melanoma have a higher incidence of Ras mutations. ${ }^{39}$ The rarity of Ras mutations in glioma makes this tumor a more appropriate target for Ras inhibition with probably low incidence of resistance to chemotherapy, as long as these tumors are tyrosine kinase receptor activated Ras-dependent. When this paper was under review, Blum et al. ${ }^{40}$ published a paper showing two of the GBM cell lines (U-87 MG and U-373 MG) used in our studies expressed N-Ras, $\mathrm{H}$-Ras and K-Ras. FTA inhibited the levels of activated Ras isoforms in these cell lines, with $\mathrm{N}$-Ras being the most affected. The paper elegantly showed that Ras inhibition downregulated hypoxia-inducible factor- $1 \alpha$, causing glycolysis shutdown and apoptosis.

In a number of published studies FTA has been shown to be effective both in vitro ${ }^{37,38}$ as well as in vivo. ${ }^{34,35,41}$ FTA crosses the blood-brain barrier and a pharmacologically relevant concentration $(4.5 \mu \mathrm{mol} / \mathrm{l})$ of the inhibitor could be rapidly reached (30-120 $\mathrm{min}$ ) following systemic administration of $3 \mathrm{mg} / \mathrm{kg}$ of the novel Ras inhibitor. ${ }^{41}$ In this study, FTA provided neuroprotection through the inhibition of active Ras in the brain. This may suggest that orally or intraperitoneally administered FTA would be bioavailable in xenograft or genetically engineered in vivo models of GBMs.

Our data also clearly suggest that other genetic alterations such as p53 and PTEN mutations do not alter the sensitivity of GBMs to FTA. We have previously reported that GBM cells expressing $\mathrm{PKC}-\eta$ were resistant to both UV and $\gamma$-radiation by preventing caspase- 9 activation. However, in this report FTA killed both PKC- $\eta$-deficient and -expressing GBM cells. Since caspase-3 or -9 mutations have not been reported in GBMs, the induction of caspase-dependent apoptosis by FTA may provide a new therapeutic paradigm for the treatment of GBMs.

\section{Materials and Methods}

\section{Materials}

Farnesylthiosalicylic acid (FTA) was bought from BIOMOL Research Lab (Plymouth Meeting, PA, USA). GGTase I inhibitor (GGTI-298), FTase inhibitor II, BIM, and U0126 are products of Calbiochem (San Diego, CA, USA). Antibody (DMA1) to tubulin was purchased from Sigma Company (St Louis, MO, USA) and a polyclonal antibody specific for human ERK1/2 was from Upstate Biotech (Charlottesville, VA, USA). The phosphospecific antibody against Akt (Ser 473) was obtained from Cell Signaling Biotechnology (Boston, MA, USA). Etoposide and antibodies against caspases-3 and PARP are products of Alexis (San Diego, CA, USA). The Pulldown Ras-GTP assay kit is from Pierce (Rockford, IL, USA).

\section{Cell culture}

Human U-251 MG (mutant p53 and PTEN) and U-1242 MG (mutant p53 and wild-type PTEN) cell lines were originally isolated from astrocytic tumors that were designated as GBMs: their PKC profiles were described previously. ${ }^{42}$ We have fully characterized and published the expression and activation levels of EGFR in two of the GBM cell lines (U-1242 MG and U-87 MG) ${ }^{43}$ EGF phosphorylates all the four tyrosine sites (Tyr845, Tyr992, Tyr1045 and Tyr1068) in both cell lines. ${ }^{43}$ EGF also induces phosphorylation of these sites in U-251 MG (unpublished observation). U-373 MG (mutant p53 and PTEN) and U-87 MG (wild-type p53 and mutant PTEN) cells were purchased from ATCC (Rockville, MD, USA). While monolayer cultures of the cell lines have significant proliferative fractions in nonconfluent growth conditions, U-1242 MG cells demonstrate a relative contact inhibition at confluence that U-251 MG or U-373 MG cells lack (data not shown). The cells were cultured to $100 \%$ confluence and passaged every 4-5 days from an initial concentration of $6-8 \times 10^{3} / \mathrm{cm}^{2}$ in $100 \mathrm{~mm}$ dishes, 6- or 24-well plates and cultured at $37^{\circ} \mathrm{C}$ in $4.8 \% \mathrm{CO}_{2}$, $90 \%$ relative humidity. All neoplastic and non-neoplastic cells were cultured in the absence of antibiotics.

\section{Cell count}

Viable cell numbers were determined by Trypan blue exclusion method. GBM cells were released from the plate with $0.05 \% \mathrm{w} / \mathrm{v}$ trypsin containing $0.53 \mathrm{mM}$ EDTA for $2 \mathrm{~min}$, centrifuged and resuspended in serum-free $\alpha$-MEM. Trypan blue stain $(0.4 \% \mathrm{w} / \mathrm{v})$ was added and cells were counted under the microscope with a hemocytometer.

\section{Thymidine uptake}

Relative rates of DNA synthesis were assessed by determination of ${ }^{3} \mathrm{H}$-thymidine incorporation into trichloroacetic acid (TCA)-precipitable material. Cells were pulsed for $4 \mathrm{hr}$ with ${ }^{3} \mathrm{H}$-thymidine $(2 \mu \mathrm{Ci} / \mathrm{ml})$ and then washed with PBS. This was followed by 10 min washes with $10 \% \mathrm{TCA}$, first at $4^{\circ} \mathrm{C}$ and then at $22^{\circ} \mathrm{C}$. Cells were then dissolved in $1 \mathrm{~N} \mathrm{NaOH}$ and placed in Ready-Safe scintillation fluid. ${ }^{3} \mathrm{H}$-thymidine incorporation was measured with a Beckman Liquid scintillation counter.

\section{Flow cytometry}

Control and FTA-treated GBM cells were analyzed for DNA content using flow cytometry. Cells were washed twice with $1 \%$ BSA/PBS solution by centrifugation ( $1500 \times g$ for $5 \mathrm{~min}$ ): $1 \times 10^{6}$ cells were resuspended in $1 \mathrm{ml}$ of staining solution $(0.1 \%$ sodium citrate, $0.1 \%$ Triton X-100, $50 \mu \mathrm{g} / \mathrm{ml}$ propidium iodide $(\mathrm{PI})$ and $100 \mathrm{U} / \mathrm{ml}$ RNAse $(1 \mathrm{mg} / \mathrm{ml})$. Cells were stained for $30 \mathrm{~min}$ at room temperature before DNA content was analyzed. Analytical cytometry was performed on a FACScaliber system using CellQuest software (Becton Dickenson, San Jose, CA, USA). Gating to exclude debris was based upon DNA fluorescence and a minimum of 40000 events were collected per sample for analysis.

\section{Caspase assay}

Apoptosis was induced in GBM cells by addition of FTA $(10 \mu \mathrm{M})$ to the cultures for $24 \mathrm{~h}$. Control cells were incubated with $0.01 \% \mathrm{v} / \mathrm{v}$ dimethyl sulfoxide (DMSO), the solvent in which FTA was dissolved. The floating 
cells were removed and centrifuged at $1000 \times g$ for $10 \mathrm{~min}$. The pellet was resuspended in $500 \mu$ l of chilled $1 \times$ Lysis Buffer (Chemicon, Temecula, CA, USA) and the resultant lysate was added to the remaining adherent cells on the plate. The cells were further incubated on ice for $10 \mathrm{~min}$ and centrifuged at $10000 \times g\left(4^{\circ} \mathrm{C}\right)$ for $5 \mathrm{~min}$. The supernatant (cytosolic extract) was collected and protein content determined. Caspase assay was performed as described by the manufacturer using specific substrate and inhibitor for caspase-3, -8 , or -9 . The samples were incubated for $1 \mathrm{~h}$ at $37^{\circ} \mathrm{C}$ and absorbance read at $405 \mathrm{~nm}$. The experiments were repeated three times for each cell line.

\section{Western blot analysis}

For the detection of pro- and cleaved caspases, PARP, or tubulin, the rinsed cultured cells were extracted with $1 \%$ Triton X-100, 0.2\% Nonidet P-40 (NP-40) in the presence of $2 \mathrm{mM}$ EDTA, $100 \mu \mathrm{M}$ phenylmethylsulfonyl fluoride, $5 \mu \mathrm{g} / \mathrm{ml}$ leupeptin and $1.0 \mu \mathrm{g} / \mathrm{ml}$ aprotinin as previously reported. ${ }^{23,34}$ MAP kinase phosphorylation was stimulated in cells that had been cultured in serum-free medium for $24 \mathrm{~h}$, by incubation with epidermal growth factor (EGF, $25 \mathrm{ng} / \mathrm{ml}$ ) for $15 \mathrm{~min}$. The incubation was terminated by the addition of ice-cold phosphate buffered saline (PBS) and extracted with $1 \%$ NP-40 buffer. ${ }^{34}$ The NP-40 extract was centrifuged at $14000 \times g$ for $15 \mathrm{~min}$, electrophoresed and immunoblotted as described previously ${ }^{9,42}$ with a polyclonal antibody specific against phosphorylated ERK-1/ERK-2 (1:10000) or Akt (1:1000).

\section{Ras activity assay}

Cells were grown to near confluency $(90 \%)$, serum-starve overnight and treated with different concentrations of EGF in the presence and absence of FTA. At the end of the incubation period, cells were solubilized with lysis buffer. The solubilized extract was centrifuged at $14000 \times g$ for $15 \mathrm{~min}$ and the supernatant used for the pulldown assay (Pierce Rockford, IL, USA). Protein content of the cell extract was determined with Bradford reagent (Bio-Rad, Hercules, CA, USA) and $500 \mu \mathrm{g}$ of protein was incubated with Raf-RBD-GST $(80 \mu \mathrm{g})$ for $1 \mathrm{~h}$ with gentle rocking. The samples were spun at $7200 \times g$ for 10-20 s and the resins were washed three times with lysis/binding/wash buffer $(7200 \times g$ for $30 \mathrm{~s})$. The final pulldown was performed with $50 \mu \mathrm{l}$ of sample buffer containing dithiothreitol $(5 \mathrm{mg} / \mathrm{ml})$ and the proteins subjected to Western blot analysis. Ras GTPase Chemi ELISA Assay was used to complement the western pulldown analysis. The Ras GTPase Chemi ELISA Kit (Active Motif, Carlsbad, CA, USA) contained a Raf-RBD protein that was fused to GTS in a 96-well coated with glutathione. The GST-Raf-RBD was incubated in the wells for $1 \mathrm{~h}$ to immobilize the captured probe. Cell lysate ( $25 \mu \mathrm{g} /$ well) was added and incubated for $1 \mathrm{~h}$. A primary antibody to panRas was added to the wells for $1 \mathrm{~h}$. The wells were washed (three times) and secondary antibody conjugated with HRP was added to each well, incubated and washed three times. Finally the product was detected with chemiluminescent $(E C L)$ reagents. The plate was read on a luminometer, which provided a sensitive and quantitative chemiluminescent readout of activated Ras.

\section{Statistics}

Results show mean \pm standard error (S.E.) with ' $n$ ' representing the number of observations. Statistical analysis of results was performed using unpaired Student's $t$-test. A probability $(P)$ value (two-tailed) of 0.05 or less was taken to indicate statistical significance.

\section{Acknowledgements}

This work was supported by grants from the National institute of Health, CA 98508 and NS35122 (IMH).

\section{References}

1. Kleiheus P and Caveness WK (2000) Tumours of the Nervous System: Pathology and Genetics Lyon: International Agency for Research on Cancer

2. Cairncross JG, Ueki K, Zlatescu MC, Lisle DK, Finkelstein DM, Hammond RR, Silver JS, Stark PC, Macdonald DR, Ino Y, Ramsay DA and Louis DN (1998) Specific genetic predictors of chemotherapeutic response and survival in patients with anaplastic oligodendrogliomas. J. Natl. Cancer Inst. 90: 1473-1479

3. Smith JS, Perry A, Borell TJ, Lee HK, O'Fallon J, Hosek SM, Kimmel D, Yates A, Burger PC, Scheithauer BW and Jenkins RB (2000) Alteration of 1p and $19 q$ as predictors of survival in oligodendrogliomas. J. Clin. Oncol. 18: 636-645

4. Chakravarti A, Delaney MA, Noll E, Black PM, Loeffler JS, Muzikansky A and Dyson NJ (2001) Prognostic and pathologic significance of quantitative protein expression profiling in human gliomas. Clin. Cancer Res. 7: 2387-2395

5. Maher EA, Furnari FB, Bachoo RM, Rowitch DH, Louis DN, Cavenee WK and DePinho RA (2001) Malignant glioma: genetics and biology of a grave matter. Genes Dev. 15: 1311-1333

6. Krishnan S, Rao RD, James CD and Sarkaria JN (2003) Combination of epidermal growth factor receptor targeted therapy with radiation therapy for malignant gliomas. Front Biosci. 8: 1-13

7. Mayo LD, Dixon JE, Durden DL, Tonks NK and Donner DB (2002) PTEN protects p53 from Mdm2 and sensitizes cancer cells to chemotherapy. J. Biol. Chem. 277: 5484-5489

8. Broaddus WC, Liu Y, Steele LL, Gillies GT, Lin PS, Loudon WG, Valerie K, Schmidt-Ullrich RK and Fillmore HL. (1999) Enhanced radiosensitivity of malignant glioma cells after adenoviral p53 transduction. J. Neurosurg. 91: 997-1004

9. Hussaini IM, Sando JJ, Carpenter JE, Redpath GT, Shaffrey ME and VandenBerg SR (2002) Protein kinase C- $\eta$ regulates resistance to UV- and $\gamma$ irradiation-induced apoptosis by preventing caspase-9 cleavage in astrocytomas. Neuro-Oncology 4: 9-13

10. Mischel PS and Cloughesy TF (2003) Targeted molecular therapy of GBM. Brain Pathol. 13: 52-61

11. Chakravarti A, Chakladar A, Delaney MA, Latham DE and Loeffler JS (2002) The epidermal growth factor receptor pathway mediates resistance to sequential administration of radiation and chemotherapy in primary human glioblastoma cells in a RAS-dependent manner. Cancer Res. 62: 4307-4315

12. Mercer JA (2000) Intercellular junctions: downstream and upstream of Ras? Semin. Cell Dev. Biol. 11: 309-314

13. Pells S, Divjak M, Romanowski P, Impey H, Hawkins NJ, Clarke AR, Hooper ML and Williamson DJ (1997) Developmentally-regulated expression of murine K-ras isoforms. Oncogene. 15: 1781-1786

14. Porfiri $E$ and McCormick F (1996) Regulation of epidermal growth factor receptor signaling by phosphorylation of the ras exchange factor hSOS1. J. Biol. Chem. 271: 5871-5877

15. Maity A, Pore N, Lee J, Solomon D and O'Rourke DM (2000) Epidermal growth factor receptor transcriptionally up-regulates vascular endothelial growth factor expression in human glioblastoma cells via a pathway involving phosphatidylinositol 3'-kinase and distinct from that induced by hypoxia. Cancer Res. 60: 5879-5886

16. Omer CA and Kohl NE (1997) CA1A2X-competitive inhibitors of farnesyltransferase as anti-cancer agents. Trends Pharmacol. Sci. 11: 437-444

17. Gelb MH (1997) Protein prenylation, et cetera: signal transduction in two dimensions. Science. 275: 1750-1751

18. Gribbs JB (1993) Lipid modification of proteins in the Ras superfamily In: GTPases in Biology Birnbaumer L, Dickey B (eds). New York NY: springerVerlag, pp 335-344

19. Zhang FL, Kirschmeier P, Carr D, James L, Bond RW, Wang L, Patton R, Windsor WT, Syto R, Zhang R and Bishop WR (1997) Characterization of 
Ha-ras, N-ras, Ki-Ras4A, and Ki-Ras4B as in vitro substrates for farnesy protein transferase and geranylgeranyl protein transferase type I. J. Biol. Chem. 272: 10232-13239

20. Whyte DB, Kirschmeier P, Hockenberry TN, Nunez-Oliva I, James L, Catino JJ Bishop WR and Pai JK (1997) K- and N-Ras are geranylgeranylated in cells treated with farnesyl protein transferase inhibitors. J. Biol. Chem. 272 14459-14464

21. Sun J, Qian Y, Hamilton AD and Sebti SM (1998) Both farnesyltransferase and geranylgeranyltransferase I inhibitors are required for inhibition of oncogenic $\mathrm{K}$ ras prenylation but each alone is sufficient to suppress human tumor growth in nude mouse xenografts. Oncogene 16: 1467-1473

22. Paz A, Haklai R, Elad-Sfadia G, Ballan E and Kloog Y (2001) Galectin-1 binds oncogenic $\mathrm{H}$-Ras to mediate Ras membrane anchorage and cell transformation. Oncogene 20: 7486-7493

23. Brunner TB, Hahn SM, Gupta AK, Muschel RJ, McKenna WG and Bernhard EJ (2003) Farnesyltransferase inhibitors: an overview of the results of preclinical and clinical investigations. Cancer Res 63: 5656-5668

24. Marom M, Haklai R, Ben-Baruch G, Marciano D, Egozi Y and Kloog Y. (1995) Selective inhibition of Ras-dependent cell growth by farnesylthiosalisylic acid. J. Biol. Chem. 270: 22263-22270

25. Nozaki M, Tada M, Kobayashi H, Zhang CL, Sawamura $Y$, Abe H, Ishii N and Van Meir EG (1999) Roles of the functional loss of p53 and other genes in astrocytoma tumorigenesis and progression. Neuro-oncology 1: 124-137

26. Herrmann C, Horn G, Spaargaren M and Wittinghofer A (1996) Differential interaction of the ras family GTP-binding proteins $H$-Ras, Rap1A, and R-Ras with the putative effector molecules Raf kinase and Ral-guanine nucleotide exchange factor. J. Biol. Chem. 271 (12): 6794-6800

27. Datta SR, Brunet A and Greenberg ME (1999) Cellular survival: a play in three Akts. Genes Dev. 13: 2905-2927

28. Xia Z, Dickens M, Raingeaud J, Davis RJ and Greenberg ME (1995) Opposing effects of ERK and JNK-p38 MAP kinases on apoptosis. Science 270: 1326-1331

29. Erhardt P, Schremser EJ and Cooper GM (1999) B-Raf inhibits programmed cell death downstream of cytochrome $c$ release from mitochondria by activating the MEK/Erk pathway. Mol. Cell. Biol. 19: 5308-5315

30. Le Gall M, Chambard JC, Breittmayer JP, Grall D, Pouyssegur J and Van Obberghen-Schilling E (2000) The p42/p44 MAP kinase pathway prevents apoptosis induced by anchorage and serum removal. Mol. Biol. Cell 11 : 1103-1112

31. von Gise A, Lorenz P, Wellbrock C, Hemmings B, Berberich-Siebelt F, Rapp UR and Troppmair J (2001) Apoptosis suppression by Raf-1 and MEK requires MEK- and phosphatidylinositol 3-kinase-dependent signals. Mol. Cell. Biol. 21: 2324-2336

32. Allan LA, Morrice N, Brady S Magee G, Pathak S and Clarke PR (2003) Inhibition of caspase-9 through phosphorylation at thr125 by ERK MAPK. Nature Cell Biol. 5: 647-654

33. Haklai R, Weisz MG, Elad G, Paz A, Marciano D, Egozi Y, Ben-Baruch G and Kloog Y (1998) Dislodgment and accelerated degradation of Ras. Biochemistry 37: $1306-1314$

34. Weisz B, Giehl K, Gana-Weisz M, Egozi Y, Ben-Baruch G, Marciano D and Gierschik $P$ and Kloog Y (1999) A new functional Ras antagonist inhibits human pancreatic tumor growth in nude mice. Oncogene 18 (16): 2579-2588

35. Jansen B, Schlagbauer-Wadl H, Kahr H, Heere-Ress E, Mayer BX, Eichler H, Pehamberger H, Gana-Weisz M, Ben-David E, Kloog Y and Wolff K (1999) Novel Ras antagonist blocks human melanoma growth. Proc. Natl. Acad. Sci. USA 96: 14019-14024

36. Clarke S (1992) Protein Isoprenylation and methylation at carboxy-terminal cystein residues. Annu. Rev. Biochem. 61: 355-386

37. Smalley KSM and Eisen TG (2002) Farnesyl thiosalicylic acid inhibits the growth of melanoma cells through a combination of cytostatic and pro-apoptotic effects. Int. J. Cancer 98: 514-522

38. McPherson RA, Conaway MC, Gregory CW, Yue W and Santen RJ (2004) The novel Ras antagonist, farnesylthiosalicylate, suppresses growth of prostate cancer in vitro. Prostate 58: 325-334

39. Rowinsky EK, Windle JJ and Von Hoff DD (1999) Ras protein farnesyltransferase: A strategic target for anticancer therapeutic development. J. Clin. Oncol. 17: 3631-3652

40. Blum R, Jacob-Hirsch J, Amariglio N, Rechavi G and Kloog Y (2005) Ras inhibition in glioblastoma down-regulates hypoxia-inducible factor- $1 \alpha$, causing glycolysis shutdown and cell death. Cancer. Res. 65: 999-1006

41. Shohami E, Yatsiv I, Alexandrovich A, Haklai R, Elad-Sfadia G, Grossman R, Biegon A and Kloog $Y$ (2003) The Ras inhibitor S-trans, transfarnesylthiosalicylic acid exerts long-lasting neuroprotection in a mouse closed head injury model. J. Cereb. Blood Flow Metab. 23: 728-738

42. Hussaini IM, Karns LR, Griffith V, Carpenter JE, Redpath GT, Sando JJ and VandenBerg SR (2000) Phorbol 12-myristate-13-acetate induces protein kinase C- $\eta$-specific proliferative response in astrocytic tumor cells. J. Biol. Chem. 275: 22348-22354

43. Amos S, Martin PM, Polar GA, Parsons SJ and Hussaini IM (2005) Phorbol 12myristate 13-acetate induces epidermal growth factor receptor transactivation via protein kinase $\mathrm{C} \delta / \mathrm{c}-\mathrm{Src}$ pathways in glioblastoma cells. J. Biol. Chem. 280: $7729-7738$ 